\title{
Technological Foresight Based on Citing and Cited Patents of Cellulose with Pharmaceutical Applications
}

\author{
Deysimar de Souza Carvalho, Leandra Guimarães de Oliveira, \\ Eduardo Winter', Cheila Gonçalves Mothé ${ }^{2}$
}

\begin{abstract}
The present study intends to present the relevance of cellulose by means of the technological foresight study through citing and cited documents from a patent application (WO 9745/3I AI) as indicators of innovation. The European database of patents (espacenet) was used, combining keywords and IPC. The major applicants, countries of publication and uses were mapped. The patent requests collected are mainly distributed in the area of polymers to medical devices and therapeutic methods that utilize cellulose. The results obtained revealed that the US was the main country with studies directed to this technological area (18 patent applications) and the major applicant was the company Micro Therapeutics Inc. Therefore, we can understand that this is a promising technology that may reflect in an increase of R\&D activities and in the patent deposits in this area.
\end{abstract}

Keywords: citing and cited documents; technological foresight; pharmaceutical patents.

\footnotetext{
' Brazilian Institute of Industrial Property (INPI-Br), Rua Mayrink Veiga, 9 - Centro, 190 Andar, CEP: 20.090-910, Rio de Janeiro, RJ, Brazil, Phone: +55 (2I) 21393767 / 21393379 / 2139-3868, (Corresponding authors) E-mail: deysimar@inpi.gov.br, leandra@inpi.gov.br, winter@inpi.gov.br

${ }^{2}$ Department of Organic Process, School of Chemsitry, Sala E-204, Federal University of Rio de Janeiro, Ilha do Fundão, CEP 2I94I909, Rio de Janeiro, RJ, Brazil. Phone +55 (2I) 2562-7587. E-mail: chaila@eq.ufrj.br
} 


\section{Introduction}

The basic premise for any country to develop technological advance activities is having a sharp scientific and technological qualification. In this context, Brazil has gradually supported the development of scientific activities that allow technological growth in various areas, making new products like pharmaceuticals and bio pharmaceuticals to be developed, and being of fundamental importance to population.

The pharmaceutical area is a research-intensive industry, which means they are always doing research, and throughout history they have presented a fast innovation rate implemented by companies in relation to other institutions. The release of new or enhanced products represents a key element in the pattern of industry competition, particularly in the pharmaceutical industry, allowing technological innovation, demanding heavy investments in research and development and that also relies on the International Intellectual Property System and massive marketing and advertising costs.

In order to have the final price of the medicine low and that the lower purchase population's access to these medicines are made easy, a great need for the development of new technologies that require processes and raw materials that produce viable pharmaceuticals is noticeable. In this case the biopolymers are considered the great promise to supply the future perspectives of this market.

In the last decades, a large number of bio molecules naturally produced in the body, are being identified as potential substances for therapeutics use. Among them the biopolymers, which are polymeric materials classified as polysaccharide, polyester, or polyamide, due to its biocompatibility. The main raw material for their manufacture is a renewable carbon source, generally a carbohydrate derived from large-scale commercial crops like sugar cane, corn, potato, wheat, sugar-beet; or a vegetable oil taken from soy, sunflower, palm, or any other oily plant (Pradella, 2006).

Currently, polysaccharide is considered a pharmacologically active molecule, mainly with anticoagulating, anti-viral, anti-tumor activities (Florêncio, et. al., 1997; Sutherland, 1998) and for cancer therapy (Calazans et. al., 1997). It also prevents diseases caused by viruses (like AIDS and influenza) and bacteria (Yalpani and
Sanford, 1987). Pharmacologically, they are classified as modifiers of the biological response. In the pharmaceutical market it is already possible to find some polysaccharides to the treatment of a few diseases.

Facing the world's demands for new compounds and therapeutic methods that prevent and treat diseases whose treatments are still a challenge to scientists nowadays (like: cancer, AIDS, cardiovascular diseases, among others), together with the high cost of biopolymers to pharmaceutical use; it is necessary to develop new technologies using these biopolymers as pharmaceutics. And, as part of the technological innovation development process, the new technologies must be protected utilizing patent rights.

Cellulose $\left(\mathrm{C}_{6} \mathrm{H}_{10} \mathrm{O}_{5}\right)_{\mathrm{n}}$ is the most abundant biopolymer (Mutwil, 2008), of variable molecular weight, composed of only one monomer (glucose), classified as polysaccharide or carbohydrate. It is one of the main elements in the membranes of plants cells (around 33\% of the plant's weight). The cellulose's structure is formed by the union of molecules of $\beta$-glucose (an hexosane) through $\beta$-I,4-glycosidic bonds (Mutwil, 2008). Cellulose is also produced by bacteria, algae, and fungi and not only by plants. It is known that few bacteria like Acetobacter xylinum have a cellulose producing capacity. This production happens as an outer cellular film that rapidly joins cellulose micro-fibers (Sutherland, 1990). The interest for bacterial cellulose has grown in the last years, leading to the appearing of various potential uses, like, for example, the acoustic diaphragm, sterile topical applicators, filter membranes, additive element to paper and dietetic fiber and their applications in medicine, and also in other products to substitute the skin and the temporary replacement of the tissue. (Falcão et al, 2008).

The use of the micro-biotic cellulose (like Acetobacter xylinum) was suggested in different areas of medicine, like: blood and lymphatic vessels substitute, hollow inner organs substitute (ureter, trachea and digestive tract), abdominal wall substitute, skin, subcutaneous tissue, articulations, cartilage, bladder suspension and hernia treatment. In human beings, it was used in wounds (burns), chronic ulcers, and leprosy, among others. (Falcão, et al, 2008).

The use of cellulose is important in the pharmaceutical industry, it is important to assess how it is implemented and how the development of research and development 
(R\&D) in the area was. In this context, the patent applications are among the most reliable and comprehensive sources of formal information when R\&D, technology, and innovation are analyzed. Patents can be considered indicators of R\&D in a particular industry and thus are directly related to the process of technological innovation, therefore, the information contained in these documents are essential for evaluating the technological overview in a particular area.

For a better analysis of patent applications, techniques applied in technological forecasting studies, such as monitoring and bibliographic studies are the most suitable, especially by the systematic use and because they have preestablished procedures worldwide, making research comparable with other studies in the area.

Technological foresight is the term applied in studies that try to anticipate and understand the potentialities, evolutions, characteristics, and effects of technological changes, particularly its invention, adoption and usage. Thus, through it, it is possible to try to anticipate the technological and scientific advances and participate in a way to influence in the guidance of technological trajectories guaranteeing competitiveness and the survival of research institutions. The main point is to identify the chances for development and the options for present action (Coelho, et al, 2003).

The Technological foresight was born in the U.S. in the 50 's. However, in the 90's there was an increase in such methodologies in developed and developing countries, once more companies and countries made use of these studies to strengthen its competitive capacity (Coelho, et al, 2003).

The methods and techniques used in foreseeing are hard to categorize. One of the categories used is the monitoring \& intelligence systems and the other one is the trend analysis. In a way that these categories emphasize how future conditions evaluations rely on present conditions (Coelho, et al, 2003).

Monitoring is the process by which pieces of information about foreseeing are monitored, identifying its sources, collecting, analyzing and structuring this information for its use. Thus, monitoring is crucial to any foresight (Coelho, et al, 2003).

Patent analysis comes from the thought that the increase of interest for new technologies will reflect in the growth

ISSN: 07I 8-2724. (http://www.jotmi.org)

Journal of Technology Management \& Innovation @ Universidad Alberto Hurtado, Facultad de Economía y Negocios of Research and Development activities and this, will lead to an increase of patent deposits. Therefore, it is thought that new technologies can be identified by the analysis of patent application in some fields. The results are generally presented quantitatively, but their use in the decisionmaking process is based on a qualitative evaluation.

In this context, the present study intends to show the relevance of cellulose by means of the technological forsight study through citing and cited documents and a patent document that utilizes cellulose in the medicinal area. With this, it intends to analyze the uptrend of the use of this macro molecule in the pharmaceutical industry, the importance of its patenting, its main application in the pharmaceutical industry as well as the major applicant (s) and the country (ies) holding the technology in order to try to anticipate the scientific and technological advances and participate in a way to influence in the guidance of technological trajectories guaranteeing competitiveness and the survival of industries and research institutions.

\section{Method}

The methodology used in the development of this paper, was done in three stages. The first one was the selection of a patent document in the medicinal area that uses cellulose in the European Patents Database, the Espacenet. The document was obtained using the keyword, "cellulose" and the international classification "A6IK3I/I75". The base ep.espacenet.com, also known as EPODOC, is formed by a collection of more than 60 million patent applications from almost all the countries in the world, existing since 1836 and weekly updated. It also offers an option of patent search by families. It is a database that contains biographic data, like: numbers and dates of publication, deposit and priority, International Patents Classification (IPC), inventors, applicant and title, citing and cited documents in the search. Thus, the patent document chosen was WO 97/45I3I, for it presented a good number of citing documents and it was cited by many other patent documents. This patent document had as its applicant the company MICRO THERAPEUTICS and describes a compound utilizing cellulose derivatives, and also the therapeutic method to treat blood vessels embolism utilizing such compound.

The second stage was the selection of cited and citing documents in the search for the patent document selected 
and its correspondents (technological evolution), which were also obtained in the espacenet database. The choice of cited and citing documents by the espacenet database is interesting, once these documents are cited in the International Preliminary Examination Report (IPER) and thus, are documents that are similar to the chosen patent document, as for they relate to state of the art.

The third stage was the indexing and treatment of collected data and the preparation of the statistics in order to determine patenting trends in cellulose in the pharmaceutical industry. The analyzed documents were evaluated in relation to the major applications, countries of publication, and types of application.

Through the IPC analysis of documents found in the search, it is expected the possibility to observe the diversity of topics in the group of collected patents.

\section{Results}

The start document was WO 97/45 I3I, which refers to a compound that includes cellulose derivate, as well as the therapeutic method to administrate this compound in order to treat blood vessels embolism.

The data taken from this document were:

$\checkmark$ Publication Date: December $4^{\text {th }}, 1997$

$\checkmark$ Deposit Date: April 25 $5^{\text {th }}, 1997$

$\checkmark$ Priority (ies) Date (s): US 08/655822 - May 31 ${ }^{\text {st }}, 1996$

US $08 / 802252$ - February $19^{\text {th }}$, 1997

$\checkmark$ Title: Compositions for use in embolizing blood vessels

$\checkmark$ applicant (s): MICRO THERAPEUTICS

$\checkmark$ Inventor (s): EVANS, Scott et al.

$\checkmark$ IPC: A6IK 33/04

By means of search on the website ep.espacenet.com, it was possible to obtain the family of this document (13 family documents), as well as the cited documents and documents that cited the document or any other document of the family, as it can be observed in the table below.

\begin{tabular}{|c|c|c|c|c|}
\hline Family Documents & $\begin{array}{l}\text { Publication } \\
\text { Date }\end{array}$ & Category & Cited & Citing \\
\hline US2003I85758 AI & Feb $10^{\text {th }} 2003$ & $\begin{array}{l}\text { Compound and } \\
\text { Therapeutic method }\end{array}$ & None & None \\
\hline US2003003056 AI & Feb It 2003 & $\begin{array}{l}\text { Compound and } \\
\text { Therapeutic method }\end{array}$ & None & None \\
\hline US2002I87I02 AI & Dec $12^{\text {th }} 2002$ & $\begin{array}{l}\text { Compound and } \\
\text { Therapeutic method }\end{array}$ & None & WO2004080503 AI \\
\hline US200207638I AI & June $20^{\text {th }} 2002$ & $\begin{array}{l}\text { Compound and } \\
\text { Therapeutic method }\end{array}$ & None & None \\
\hline US200I $024637 \mathrm{AI}$ & Sept $27^{\text {th }} 200 \mathrm{I}$ & $\begin{array}{l}\text { Compound and } \\
\text { Therapeutic method }\end{array}$ & None & WO2004035093 A2 \\
\hline US6342202 BI & Jan $29^{\text {th }} 2002$ & $\begin{array}{l}\text { Compound and } \\
\text { Therapeutic method }\end{array}$ & $\begin{array}{l}\text { US4847065 A } \\
\text { US4999188 A } \\
\text { US5525334 A } \\
\text { US570236I A }\end{array}$ & None \\
\hline
\end{tabular}

(Continued on next page) 
(Continued from previous page)

\begin{tabular}{|c|c|c|c|c|}
\hline WO9745I3I Al & $\begin{array}{c}\text { April 12 } 2^{\text {th }} \\
1997\end{array}$ & $\begin{array}{l}\text { Compound and } \\
\text { Therapeutic method }\end{array}$ & $\begin{array}{l}\text { WO8500969 Al } \\
\text { WO9704657 Al } \\
\text { WO9704656 AI } \\
\text { WO97048I3 AI } \\
\text { XP002038436 A } \\
\text { XP002038437 A } \\
\text { XP0020382I5 A }\end{array}$ & $\begin{array}{c}\text { USRE39456 EI } \\
\text { AU200420I529 AI } \\
\text { WO2004028569 AI } \\
\text { WO02089863 AI } \\
\text { WO0I03666 A2 } \\
\text { US6558367 BI } \\
\text { WO0028920 Al } \\
\text { WO9956783 AI } \\
\text { EPI028758 AI } \\
\text { US6059766 A }\end{array}$ \\
\hline JP200I509I33T T & Oct $7^{\text {th }} 2001$ & $\begin{array}{l}\text { Compound and } \\
\text { Therapeutic method }\end{array}$ & None & None \\
\hline EP0928I95 Al & Jul $14^{\text {th }} 1999$ & $\begin{array}{l}\text { Compound and } \\
\text { Therapeutic method }\end{array}$ & None & None \\
\hline DE697I8I80T T2 & Aug $21^{\text {st }} 2003$ & $\begin{array}{c}\text { Compound and } \\
\text { Therapeutic method }\end{array}$ & None & None \\
\hline CA22527I8 Al & Apr $12^{\text {th }} 1997$ & $\begin{array}{c}\text { Compound and } \\
\text { Therapeutic method }\end{array}$ & None & None \\
\hline$A \cup 2745497 \mathrm{~A}$ & May $5^{\text {th }} 1998$ & $\begin{array}{c}\text { Compound and } \\
\text { Therapeutic method }\end{array}$ & None & None \\
\hline AT230269T T & Jan $15^{\text {th }} 2003$ & $\begin{array}{l}\text { Compound and } \\
\text { Therapeutic method }\end{array}$ & None & None \\
\hline
\end{tabular}

Table I. Citing and cited documents in the WO $97 / 45 \mathrm{I} 3 \mathrm{I}$ family

We can observe that these documents, as well as the ones that belong to the same family are of great importance in the technological area when referring to the use of cellulose in the pharmaceutical industry, once, in spite of being a rather new document (1997), it has been cited by 12 other patent documents and cited $1 \mathrm{I}$ documents in its descriptive report. Making a total of 24 documents (3 being of non-patent literature). However, a more careful analysis allow to expand even more this universe of documents, once another range of documents related to the same can be obtained by means of detailed reading of the cited documents in the patent body or by means of a search made by each examiner from each national patent office, where these applications were deposited. Together with this, relevant documents cited during opposing or invalidity procedures can also emerge.

From figure I below 8 out of 22 different identified applicants to the 21 patents obtained in the search are shown. Therefore, it's observed that the major applicant is Micro Therapeutics INC with II patent applications, followed by Biocompatibles UK LTD with 2 patent applications. 


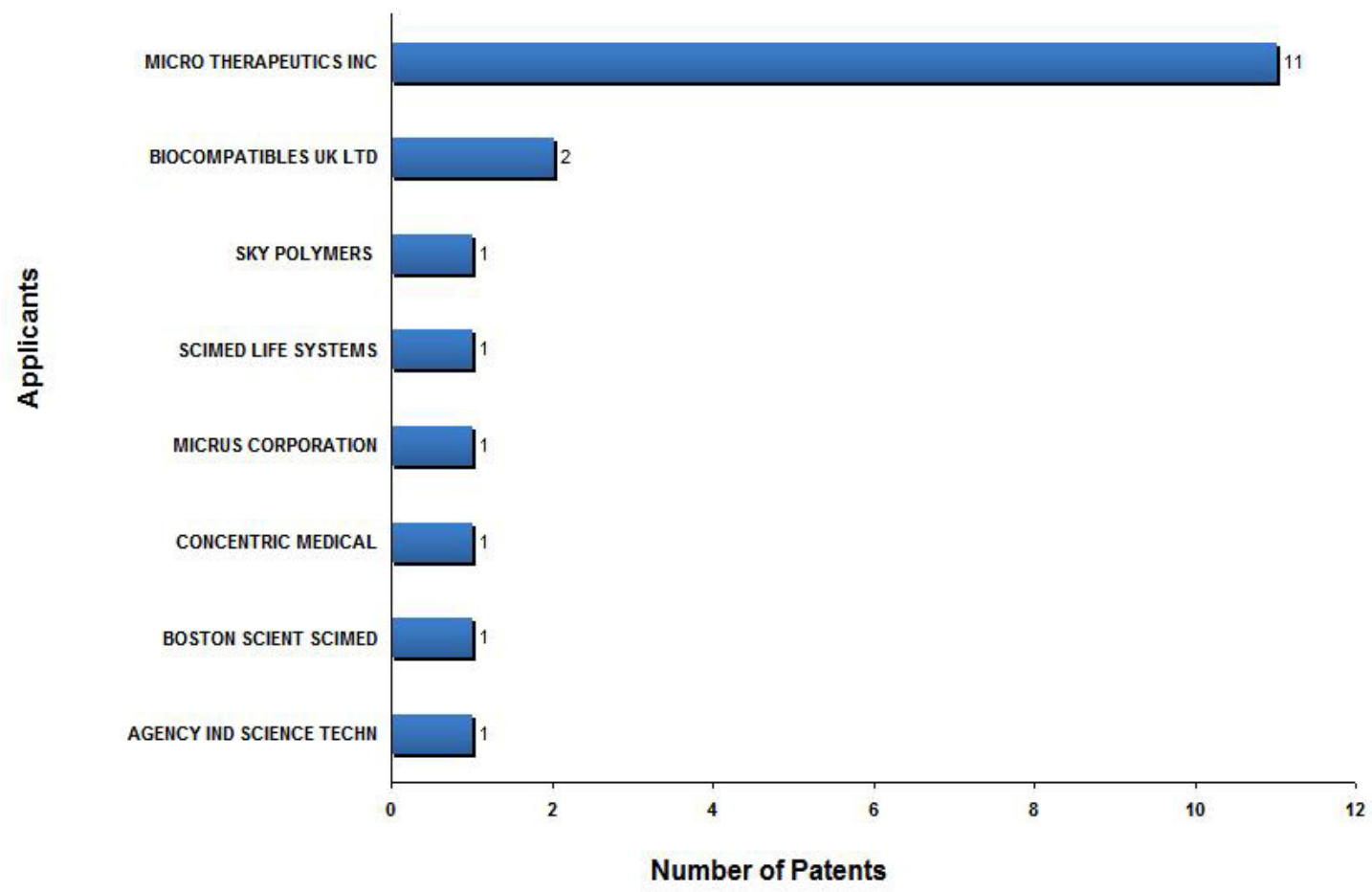

Figure I. Main depositors by number of patent applications.

Table 2 below shows a statistic of the major assignees in this technological area and its uses. As it can be observed, the major assignee is Micro Therapeutics, whose operating area is polymers to medical devices and therapeutic methods.

\section{Applicant}

AGENCY IND SCIENCE TECHN

BIOCOMPATIBLES UK LTD

BOSTON SCIENT SCIMED

CONCENTRIC MEDICAL

MICRO THERAPEUTICS INC

MICRUS CORPORATION

SCIMED LIFE SYSTEMS INC

SKY POLYMERS

$\mathbf{N}^{\circ}$ of
patents

I Polymers to medical devices

2 Polymers to medical devices

I Polymers to medical devices

I Polymers to medical devices

II Polymers to medical devices

I Polymers to medical devices

I Polymers to medical devices and medical instruments

I Polymers to medical devices

Table 2. Key applicants and sector of activity 
From figure 2 below, it is possible to understand that the main holder of technology is the U.S., once 19 of the patent applications had its origin in this country, which represents $90 \%$ of applications followed by Britain and Australia, with 5\% each. Also, I3 applications were assigned directly in the World's Intellectual Property
Office (WIPO), via PCT, like WO, what represents $62 \%$ of the patent documents. This result indicates that these companies are not only thinking in the domestic market, but to ensure their protection in other countries in a globalized economy.

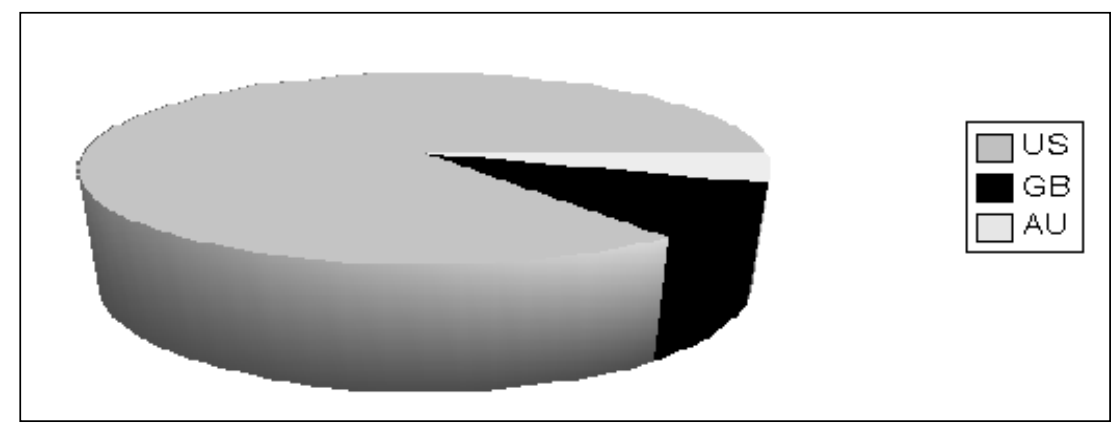

Figure 2. Graphic of origin of patent application - distribution by country.

Figure 3 below shows the major inventors out of the 64 identified. It is noticeable that the major inventor is Greff Richard J. that appears in 9 patent documents followed by Evans Scott, with 5 patent documents. Therefore, it can be stated that the researcher Greff R. J., together with Evans S., based on this case study, come to be two of the experts who have shown a high degree of development in the area. It is noticeable that the two act in Micro Therapeutics.

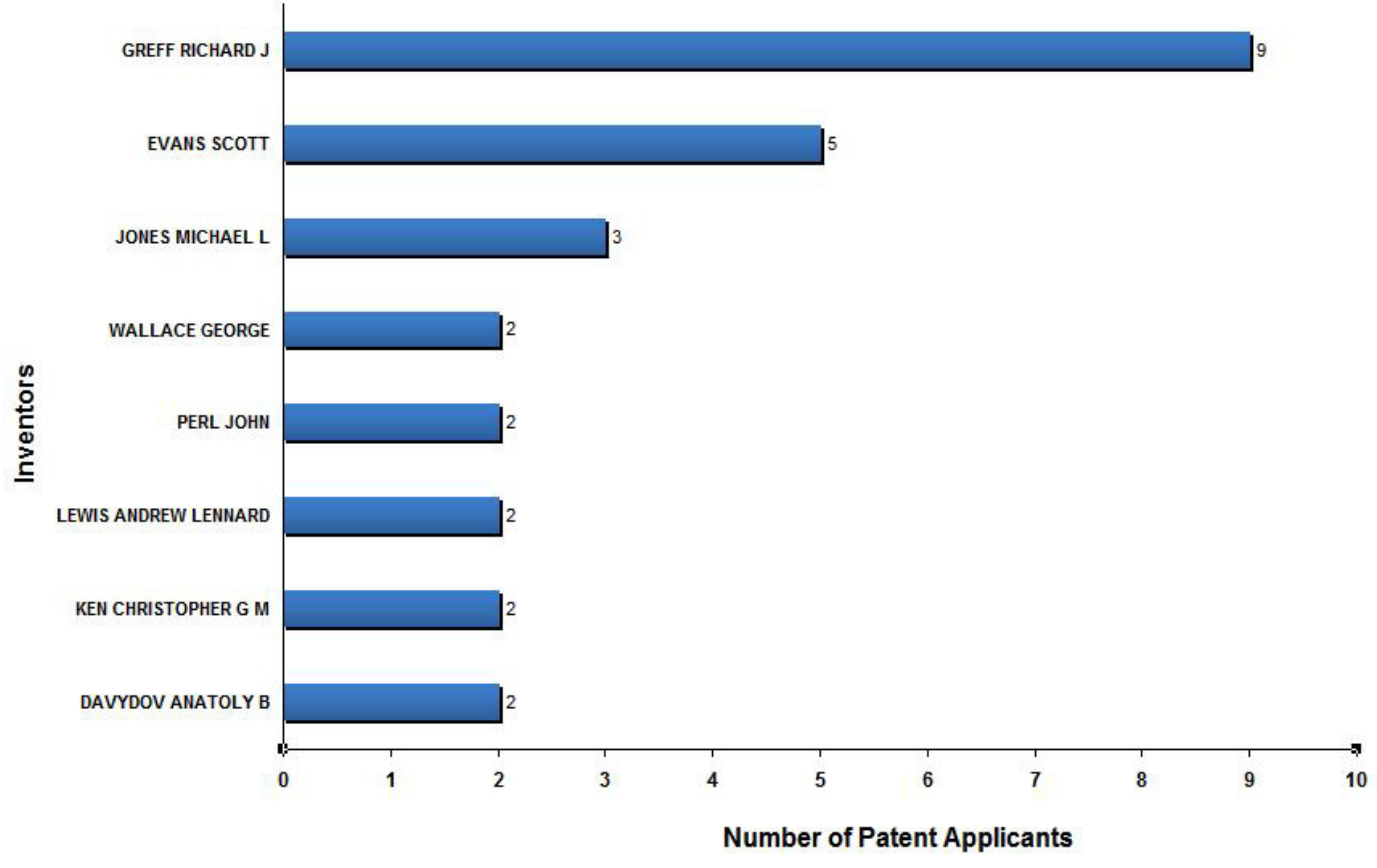

Figure 3. Graphic of major invertors by number of patents. 
Also, an invention is usually classified according to its nature or intrinsic function, except when its application alone determines its technical features. Thus, we can make an evaluation of the technological areas involved in the use of cellulose using IPC as a reference.

According to the information above, it seems that the use of the IPC as a source of information is extremely necessary when evaluating this technological area, since it may have different applications for cellulose in different areas.
From the documents collected various different classifications were taken, where the main one was the A6IK, this classification toward to preparation for medical, dental or toilet purposes (International Patent Classification), which refers to the medicinal preparations, which appears 40 times in the analyzed patent documents, as it can be observed in picture 4 below.

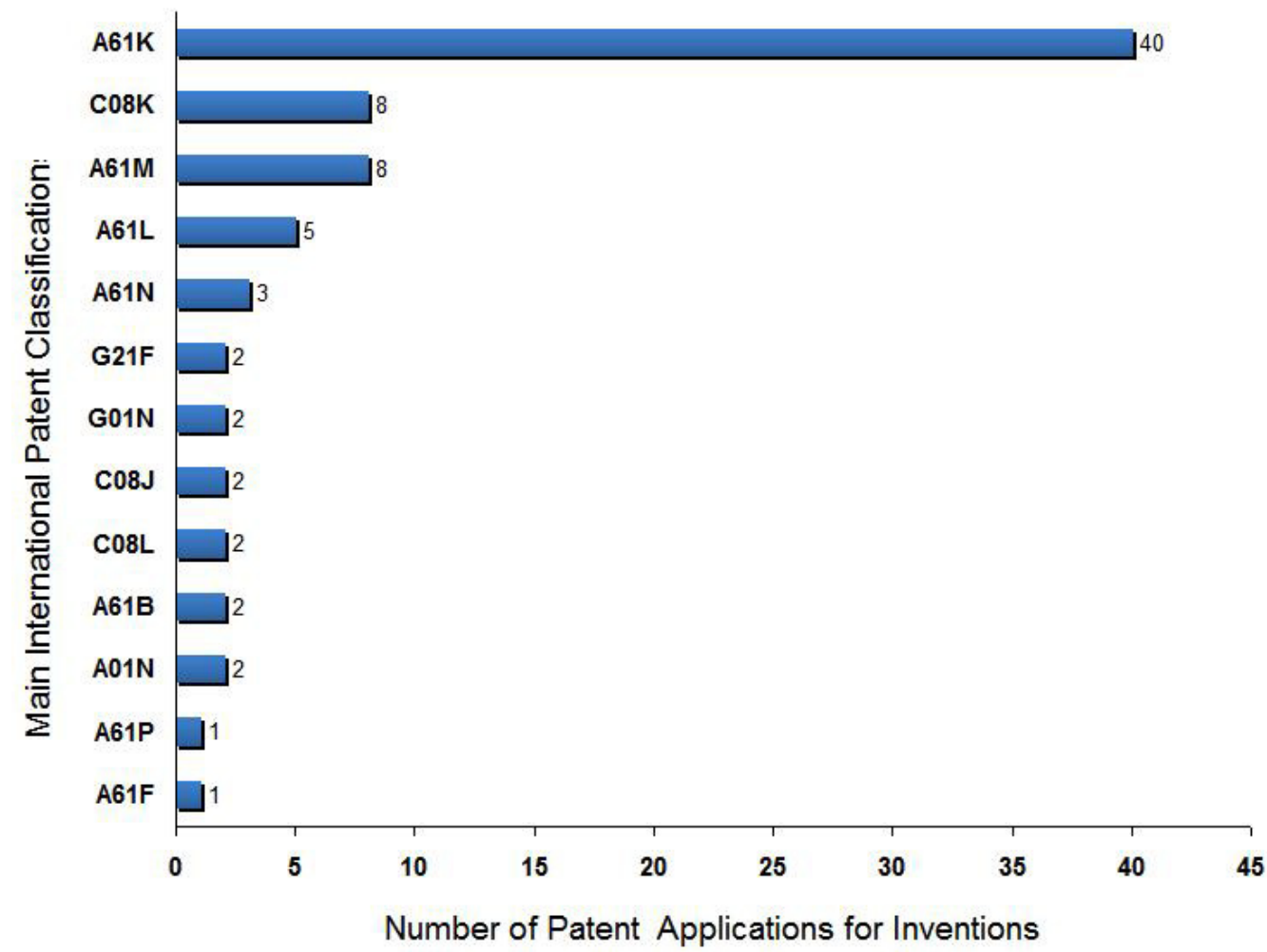

Figure 4. Main international patent classifications obtained in the query - by number of patent applications

The expansion of the subclass A6IK in the groups can be observed in picture 5 below, where it's evident that the A6IK 3 I group (Medicinal preparations containing organic active ingredients) is the most relevant one, followed by the A6IK 49 group (Preparations for testing in vivo), A6IK 47 group (Medicinal preparations characterized by the non-active ingredients used, e.g. carriers, inert additives) and A6IK 33 group Medicinal preparations containing inorganic active ingredients. It is valid to stress that this analysis considers all the subgroups appearing in the analyzed patent documents, once each patent can have more than one international classification to refer to all protection categories claimed.

This result shows the wide range for the use of cellulose in the medicinal, applied in compounds with an organic or inorganic active ingredient and even applied to preparations for in vivo tests, which can be explained by the greater availability of this polymer. 


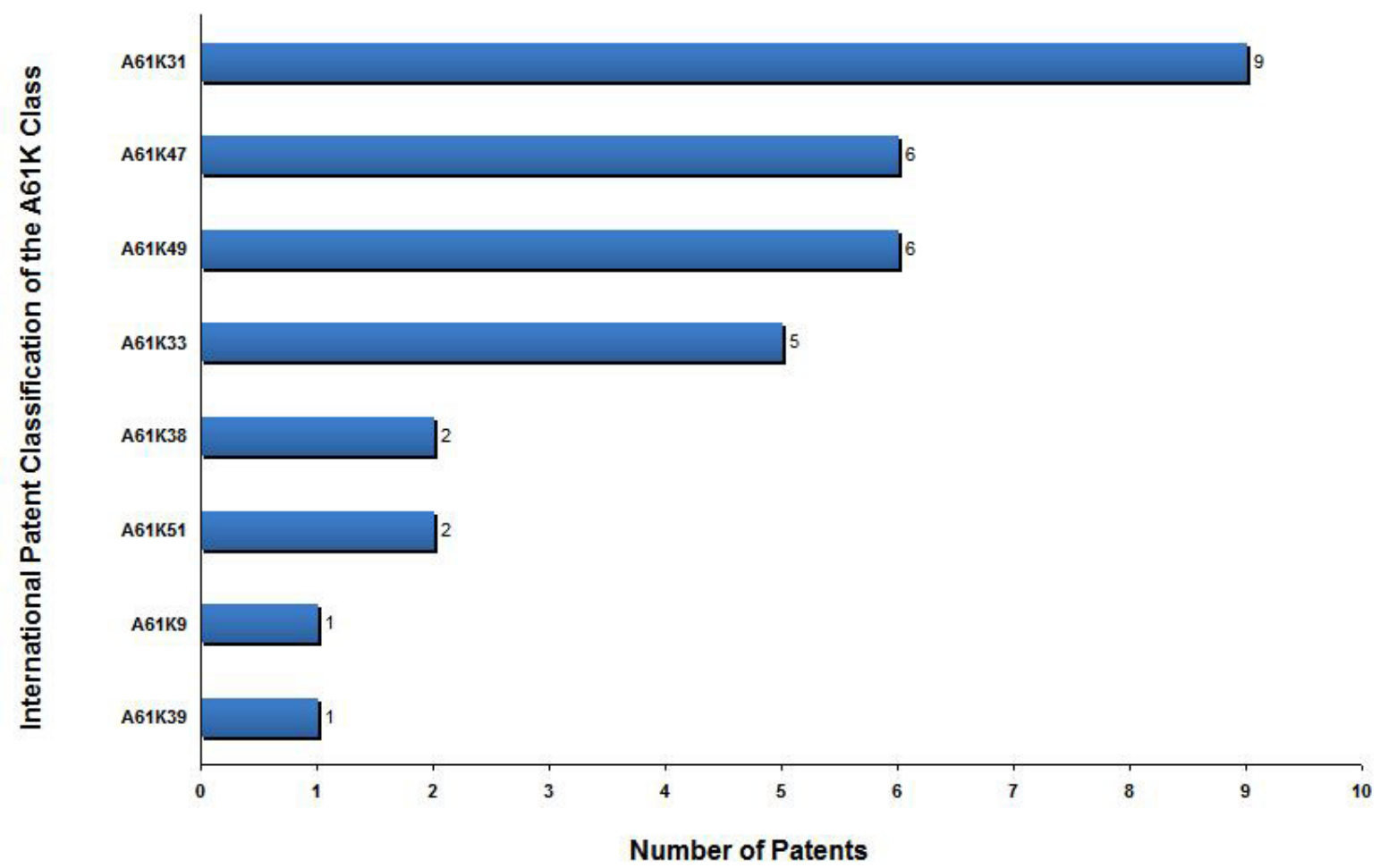

Figure 5. Patent application obtained in the query using the International patent classification (A6IK class)

\section{Discussion}

The present study represented an analysis of the technological evolution related to the bio polymer cellulose in the pharmaceutical industry utilizing citing and cited patent applicants from a patent application (WO $97 / 45|3| \mathrm{Al}$ ) as innovation indicators.

Accordingly, 21 documents for patent application were obtained and 3 of non-patent literature. In which the major applicant of patent application about the use of cellulose in the pharmaceutical industry was the company Micro Therapeutics Inc. that works in the area of polymers to medical devices, but other companies also appear in the study, showing a diversity of actors involved in the sector.

The patent application found are mainly distributed in the area of polymers to medical devices followed by a therapeutic method that utilizes cellulose.

By analyzing the countries where the patent application originated from, as well as countries where they were requested, it was observed that they mainly originated from the U.S. (I 8 requests) But other and the vasmajority of applications were filed via the PCT (13 requests), indicating the demand for protection of various countries, a result that reflects the current globalization experienced by technology and most of the applications were filed via PCT ( 13 applications), indicating that many countries rely on protection, and this result reflects the current globalization experienced by technology.

Also, by means of IPC, it is verified that cellulose has acquired many uses, like organic or inorganic active ingredients and even in preparations for in vivo determinations, indicating the possibilities of its use.

From the patent application analyzed, it was also observed that there isn't a concentration of patent applications in only one company, depicting that many companies look for patent protection when it comes to the use of cellulose in the pharmaceutical industry.

From the exposed above, it can be understood that the application of cellulose in the pharmaceutical industry is a promising technology that has as its major technology holder the U.S. 


\section{References}

CALANZANS, G. M. T., Lopes, C. E., Lima, R. M. O. C., França, F. P. (1997). Antitumor activities of levans produce by Zymomonas mobilis strains, Biotechnology Letters, v. 19, $\mathrm{n}^{\circ}$ I, p. |9-2I.

COELHO, G. M.; Coelho D. M. S. (2003). Metodologias e Experiências Nacionais e Internacionais, - Nota Técnica 14 , Instituto Nacional de Tecnologia, Janeiro/2003.

FALCÃO, S. C., Coelho, A. R. B., Evêncio Neto, J. (2008). Acta Cirurgica Brasileira, v. 23, $n^{\circ}$ 2, São Paulo.

FLORÊNCIO, A. P. S., Melo, J. H. L., Mota, C. R. F. C., Melo-Júnior, M. R., Araújo, R. V. S. (2007). Revista Eletrônica de Farmácia, v. IV(I), p. 6I-65, 2007.

MUTWIL, M., Debolt, S., Persson, S. (2008). Current Opinion in Plant Biology, I I, p. 252-257.

PRADELLA, J. G. C. (2006). Biopolímeros e intermediários químicos, Relatório Técnico ${ }^{\circ} 84396$ - 205, Laboratório de Biotecnologia Industrial - LBI/CTPP, São Paulo, 2006.

Retrieved from the Web 10/10/09. http://ep.espacenet.com

Retrieved from the Web 10/10/09. http://www.uspto.gov

SUTHERLAND, I. W. (1998). Novel and Established Applications of Microbial Polysaccharides, Trends in Biotechnology, v. I6, $n^{\circ}$ I, p. 4I-46,.

SUTHERLAND, I. W. (1990). Biotechnology of Microbial Exopolysaccharides, Cambridge: Cambridge University Press, p. 163.

YALPANI, M., Sandford, P. (1987). Commercial Polysaccharides: Recen Trends and Developments. In: Industrial polysaccharides - Progress in Biotechnology, Elsevier Science Publishers, Amsterdam, v. 3, p. 3I I-336. 